JSIP: Jurnal Studi Ilmu Pemerintahan

Volume 2, No 2 Agustus 2021

ISSN: 2722-7405

\title{
IMPLEMENTASI E-GOVERNMENT PADA PEMERINTAH DAERAH
}

\begin{tabular}{|c|c|}
\hline \multicolumn{2}{|c|}{$\begin{array}{c}\text { Rudi Deswanto }{ }^{2} \\
\text { Sri Adhi Ningsih }{ }^{3} \\
\text { Mahasiswa Ilmu Pemerintahan Universitas Muhammadiyah Buton } \\
\text { Email: karman umbuton@gmail.com }\end{array}$} \\
\hline Article Info & \\
\hline $\begin{array}{l}\text { Keyword: } \\
\text { Public Service }{ }^{1} \text {, E- } \\
\text { Government }^{2} \text {, } \\
\text { Government System }^{3} \text {. }\end{array}$ & $\begin{array}{l}\text { Abstract: E-Government or Electronic-Based Government System is a concept } \\
\text { carried out by government institutions in providing services to the community } \\
\text { more effectively and efficiently. There are problems that continue to occur related } \\
\text { to the development of the Electronic-Based Government System, namely the } \\
\text { security sector. The security sector must be the focus in implementing public } \\
\text { services. The amount of information that must be managed with a high level of } \\
\text { sensitivity. Serious attention is needed on how safe conditions are in developing } \\
\text { the implementation of an Electronic-Based Government System. This study uses } \\
\text { the Systematic Literature Review method to be able to identify and analyze } \\
\text { research trends related to the level of security in Electronic-Based Government } \\
\text { Systems collected from } 2015-2019 \text {. The results of this study indicate that there } \\
\text { are many factors that require the government to prioritize more safety factors in } \\
\text { implementing SPBE. In addition, there are various solutions in the form of } \\
\text { models/frameworks in solving problems in applying the concept of security to an } \\
\text { Electronic-Based Government System. }\end{array}$ \\
\hline $\begin{array}{l}\text { Kata Kunci: } \\
\text { Pelayanan Publik }^{1}, \text { E- } \\
\text { Government } \\
\text { Sistem } \\
\text { Pemerintahan } 3 \text {. }\end{array}$ & $\begin{array}{l}\text { Abstrak: E-Government atau Sistem Pemerintahan Berbasis Elektronik adalah } \\
\text { sebuah konsep yang dilakukan oleh institusi pemerintah dalam memberikan } \\
\text { layanan kepada masyarakat dengan lebih efektif dan efisien. Ada masalah yang } \\
\text { terus terjadi terkait dengan perkembangan Sistem Pemerintahan Berbasis } \\
\text { Elektronik yakni sektor keamanan. Pada sektor keamanan harus menjadi fokus } \\
\text { dalam melakukan penerapan layanan publik. Banyaknya informasi yang harus } \\
\text { dikelola dengan tingkat sensitivitas yang cukup tinggi. Dibutuhkan pemetaan } \\
\text { serius tentang bagaimana kondisi aman dalam pengembangan implementasi } \\
\text { Sistem Pemerintahan Berbasis Elektronik. Penelitian ini menggunakan metode } \\
\text { Kajian Pustaka Sistematis untuk dapat mengidentifikasi dan menganalisis tren } \\
\text { penelitian yang terkait dengan tingkat keamanan pada Sistem Pemerintahan } \\
\text { Berbasis Elektronik yang dikumpulkan dari 2015-2019. Hasil penelitian ini } \\
\text { menunjukkan bahwa banyak faktor yang mengharuskan pemerintah untuk } \\
\text { memprioritaskan lebih banyak faktor keselamatan dalam menerapkan SPBE. } \\
\text { Selain itu, ada berbagai solusi dalam bentuk model /kerangka kerja dalam } \\
\text { menyelesaikan masalah dalam menerapkan konsep keamanan ke Sistem } \\
\text { Pemerintahan Berbasis Elektronik. }\end{array}$ \\
\hline
\end{tabular}

\section{PENGANTAR}

Perkembangan Teknologi Informasi (TI) merupakan fenomena yang mampu mengubah ekosistem kehidupan dengan sangat cepat. Tidak hanya menguntungkan di dunia industri sebagai media untuk meningkatkan kinerja produksi, tetapi juga mempengaruhi tingkat gaya hidup individu. TI sangat membantu dalam mengatasi masalah dengan lebih akurat, efektif, efisien, dan aman. Kemudahan yang didapat, menjadikan kebutuhan TI menjadi salah satu hal yang harus diperhatikan termasuk pada sektor pemerintah tidak terkecuali.

Memanfaatkan TI dalam menyediakan informasi dan layanan bagi masyarakat, swasta, dan urusan yang berkaitan dengan pemerintah baik admistrasi maupun layanan publik adalah konsep dasar Sistem Pemerintahan Berbasis Elektronik (SPBE). Dengan harapan ini, pemerintah dapat meningkatkan layanan, meningkatkan transparansi, mengurangi biaya administrasi, dan

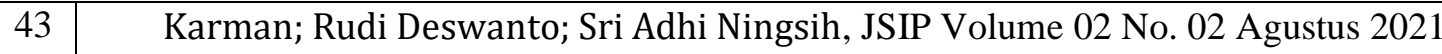


mendukung penciptaan kebijakan publik yang lebih demokratis yang lebih diterima oleh publik. Untuk alasan ini, proses perencanaan dan evaluasi harus dilakukan untuk menghasilkan produk TI yang dapat diterima di masyarakat. Salah satu aspek penting dalam desain dan implementasi SPBE adalah sektor keamanan. Dengan begitu banyak data yang dikelola dan sensitivitasnya, tingkat keamanan telah menjadi hal mendasar yang harus dipertimbangkan. Dalam tulisan ini, penulis mencoba menjelaskan berbagai pustaka yang berhubungan dengan SPBE dalam hal keamanan. Kajian pustaka sistematis yang diambil dari berbagai sumber yang kemudian dilakukan proses seleksi untuk menghasilkan 15 pustaka yang paling relevan.

Berdasarkan Instruksi Presiden Republik Indonesia Nomer 3 Tahun 2003 tentang Kebikajan dan Strategi Nasional Pengembangan E-Government ("www.hukumonline.com,," 2004) $a$ da 6 strategi dalam pengembangan E-Government yaitu: Pengembangan sistem pelayanan yang handal, terpercaya, terintergrasi dan bisa mudah dijangakau oleh masyarakat-masyarakat yang berada di seluruh penjuruIndonesia. Mencakup urusan perluasan serta peningkatan dalam kualitas pelayanan, pembentukan portal-portal yang mendukung jaringan dan pengamananya; Penataan dalam sistem dan menejemen secara sentralistik pada proses kinerja semua instansi pemerintahan yang saling berkait untuk memanfaatkan kemajuan teknologi komunikasi secara cepat dan tepat. Yang memfokuskan segala hal untuk kebutuhanmasyarakat, penguatan kepemimpinan dan pengrasionalan landasan dan peraturan dalam pengoprasian; Pengoptimalandan pemanfaatan kemajuanteknologi informasi sesuai dengan keahlian dan kemampuan dalam pengelolaan sesuaia dengan standarisasi dan landasan perumusan kebijakan; Peningkatan peran dan pengembangan teknologi komunikasi dan telekomunikasi dengan memnfaatkan bidang-bidanag untuk menciptakan dan memenuhi kebutuhan masyarakat; Pengembakan pada sumber daya manusia (SDM) dan peningkatan pendaya gunaaan yang merupakan suatu faktor utama penentu sukses atau tidaknya pengembangan E-Government. Hal tersebut bisa dengan peningkatan pemahaman dan kesadaran, peningkatan sumber daya pendidikan atau intasnsi pendidik serta penngkatan dalam motivasi yang bisa membangkitkan semangat kerja; Pelaksaan yang diselenggarakan secara sistematik dengan tahap yang realistic, teratur dan terukur. Pengembangan ini bertahap dengan empat pengukuran lagi yaitu pertama persiapan yang meliputi pembuatan situs serta penyiapan sumber daya manusia, sarana dan prasarana kemudian sosialisai situs yang akan di implementasikan. Kedua pematangan dalam pembuatan situs yang bersifat interaktif dan berhubungan dengan lembaga lain. Ketiga pemantapan adlah tahap dimana pembuatan situs- situs dan aplikasi-aplikasiyang telah direncanakan bersama dengan keterhubungan antar lembaga lain, tahap terakhir ke empat adalah pembuatan situs yang bersifat terintegrasi dan sesuai standar kulitas serta sesuai dengan persaratanE-Government/SPBE adalah hal yang banyak digunakan. E-Government telah berevolusi dari bentuk aslinya sebagai situs web onlineyangbertujuan sebagai media informasi yang berkaitan dengan institusi tertentu menjadi sistemlayanan terintegrasi yang tidak hanya satu institusitetapi institusi lain yang saling berhubungan. Selain itu mengubah fungsi interaksi satu arah, yaitu dari pemerintah ke masyarakat menjadi interaksi dua arah, yaitu fungsi di mana masyarakat dapat berkomunikasi secara langsung dengan pemerintah. Setidaknya ada tiga masalah yang terjadi, yaitu:

1. Pemerintah harus mengadakan dan memeliharafasilitasmereka sendiri. Hal ini menghasilkan sampah limbah, tidak hanya dari sistem, tetapi juga kebutuhan akan sumber daya manusia.

2. Sistem yang dibangun masing- masing di setiap unit/dinas/ departemen, di mana setiap sistem dibangun terisolasi dan tidak membuka integrasi. Hal ini mengakibatkan sulitnya untuk pengembangan dan perubahan.

3. Tingkat keamanan sistem yang tidak dapat dijamin. Ini karena masih sangat sedikit pengetahuan dan prioritas tentang keamanan TI pustaka. Pada langkah pertama persyaratanuntuktinjauan sistematis diidentifikasi. Kemudian, tinjauan sistematis dilakukan pada pustaka yang berkaitan dengan penerapan keamanan di E- Government. Tahap berikutnya, protokol hasil tinjauan dipersiapkan untuk mengarahkan pelaksanaan tahap berikutnya dan mengurangi kemungkinan bias peneliti. Tahap selanjutnya adalah 
mendefinisikan pertanyaan penelitian, strategi pencarian, dan proses pemilihan studi dengan kriteria inklusi dan eksklusi. Kemudian kualitas penelitian dinilai, dan tahap terakhir adalah proses ekstraksi dan sintesis data. Protokol peninjauan dikembangkan, dievaluasi dan ditingkatkan secara iteratif selama tahap implementasi peninjauan dan pelaporan.

Berdasarkan Undang-Undang Nomor 3 Tahun 2003 bahwa mengingat kemajuan teknologi dan informasi sangat berkembang pesat dengan kemudahan-kemudahan yang akan bermanfaat dalam bidang-bidanng pemerintahan. Dengan meningkatkan efektivitas, efisiensi, akuntabilitas dan tranparansi yang akan dubangun untuk lebih menambah kemudahan dalam memberikan pelayanan publik kepada masyarakat ("www.hukumonline.com," 2004) serta bermula dari manfaat-manfaat kemudahan yang disuguhkan E-Government sebagai contoh pada bidang komunikasi dan sistem administrasi yang berubah secara drastis yakni yang biasanya pengurusan administrasi berjalan dalam hitungan jam bahkan hitungan hari menjadi lebih efisien dalam kecepatan pelayanan. Selain itu, semua yang bersangkutan dengan pemerintahan bisa diakses secara terbuka oleh masyarakat-masyarakat luas dengan demikian bisa menumbuhkan rasa percaya masyarakat pada pemerintahan dan meminimalisir terjadinya Korupsi, Kolusi dan Nepotisme (Edwi, 2008). Adapun faktor-faktor lainyang mempengaruhipengimplementasian $E$ Government di Indonesia dalam (Hardjaloka, 2014) adalah:

1. Banyaknya kasus korupsi yang melanda pemerintahan di Indonesia yang mana muncul karena sifat monopoli pemerintah yang ingin memegang kekuasaan seluruh pemerintahan dengan mengendalikan segala potensi yang ada di Negara ini.

2. Adanya banyak penyalahan gunaan wewenang (Diskresi) oleh pejabat-pejabat pemerintahan dan pejabat publik dengan begitu terbuka lebarnya korupsi dan pungutan liat dalam penurusan perizinan yang dimana terjadi karena prosedur yang panjang dan sangat kompleks.

Minimnya kepercayaan masyarakat kepada pemerintahan dan pertanggung jawaban pejabat pemerintahan terlihat pada cara pengambilan keputusan dan tindakan-tindakan yang dimana dipercayai dengan menerapkan teknologi komunikasi dan informasi kedalam bidang pemerintahan untuk meningkatkan keterbukaan pemerintahan dan partisipasi masyarakat.

Sesuai dengan Instruksi Presiden Republik Indonesia Nomer 3 Tahun 2003 tentang Kebikajan dan Strategi Nasional Pengembangan E-Government sebagai suatu landasan dan pedoman dalam pelaksanaan dalam pemberian pelayanan umum untuk masyarakat berdasarkan pemanfaatan kemajuan teknologi komunikasi dan informasi (Data \& Dan, 2006). Pemanfaatan teknologi yang ada diinstruksikan juga untuk dimanfaatkan dalam lingkungan pemerintahan agar tercapainya tata kelola pemerintahanyang baik. Sehingga pemerintah Indonesia mengeluarkan kebijakan-kebijakan terkait pengimplementasian E-Government dengan mengeluarkan peraturan dan mengedarkan surat kepada seluruh pemerintah daerah di Indonesia untuk menerapkan sistem E-Government.

1. Peraturan Menteri Komunikasi dan Informatika Republik Indonesia Nomor 5 Tahun 2015 tentang Registrar Nama Domain Instansi Penyelenggara Negara. Adapun isi dari Peraturan Menteri ini adalah menginstruksikankepada seluruh pemerintah daerah untuk mendaftarkan nama domain untuk kebutuhan instansi, yang dimaksud dengan nama domain adalah alamat internet dari masng-masing intansi yang bisa di gunakan untuk menjalin komunikasi dan hubungan berupa kode atau susunan karakter yang mencirikhaskan daerah tersebut. Dan kegunaan dari nama domain tersebut adalah untuk mempermudah pemerintah dalam memberikan layanan domain kepada masyarakatnya dengan penyelenggara dari pemerintahan yaitu di tingkat pusat meliputi eksekutif, legislatif dan yudikatif sedangkan peneyelenggara yang berada di tingkat daerah adalah pemerintah daerah provinsi, kabupaten atau kota serta pemerintahan desa yang dibentuk sesuai peraturan perundang-undangan yang berlaku (menkominfo, 2015).

2. Surat Edaran dari Menteri Pemberdayaan Aparatur Negara pada tanggal 31 Maret 2009 tentang Pemanfaatan Perangkat Lunak Legal dan Open Software (OSS) yang diedarkan kepada Para Menteri Kabinet Indoneisa Bersatu, Panglima TNI, Jaksa Agung, Kepala 
Kepolisian Republik Indonesia, Gubernur Bank Indonesia, Pimpnan Lembaga Pemerintah Non-Departemen, Para Pemimpin kesektariatan Lembaga Negafa dan Lembaga Lainnya, Para Gubernur, Para Bupat atau Walikota dan Direksi BUMN, adapun surat edaran ini berisi himbauan atau perintah mewajibkan kepada pemerintah pusat dan pemerintah daerah untuk menggunakan perangkat lunak legal pada lingkugan pemerintahan bertujuan untuk menghindari terganggunya pelayanan publik. Pemerintah Indonesia mendeklarasikan gerakan Indonesia Go Open Source atau IGOS- I pada tanggal 30 juni 2004 yang di ikuti da tanda tangani 5 (lima) menteri yaitu Menteri Negara pemberdayagunaan Aparatur Negara, Menteri Negara Riset dan Teknologi, Menteri Pendidikan Nasional, Menteri Hukum dan Ham serta Menter Komunikasi dan Informasi. Setelah itu dilakukan lagi sebagai upaya perluasan pada 18 (delapan belas) kemeterian pemerintah dan Lembaga Non-Departmen (LPND) yang disebut IGOS-II guna memperluas dan memperdalam agar pemerintah lebih mudah dan mengerti dalam menerapkanElectronicGovernmentdalamlingkungandanbadanpemerintahan $\quad(9002$ (يوسوملا,

\section{METODE PENELITIAN}

Metode adalah langkah pertama untuk bisa mencapai tujuan dan penelitian adalah sarana atau alat untuk dalam mendapat kan tujuan akhir atau menjalankan metode penelitian. Sehingga Metode penelitian adalah salah satu tahap yang digunakan untuk mencapai tujuan dalam penelitian yaitu untuk mengetahuai sebab akibat suatu fenomena atau masalah (Sarnawi, 2012). Dalam paper ini jenis penelitian yang peneliti gunakan adalah penelitian kualitatif, yang mana topik yang peneliti angkat dalam paper ini memerlukan eksplorasi dan data banyak yang peneliti kumpulkan dengan mengeksplorasi ke berbagai web-web untuk mendapatkan informasi yang akurat (miftahuddin, 2018). Adapun metode penelitian kualitatif menurut Sugiyono (2009) metode penelitian ini meneliti kajian dalam kondisi yang alamiah dengan mengumpulkan gabungan dari data-data yang telah dikumpulkan dan di analisis dengan sifat data yang cenderung induktif dengan cara berfikir yang positif serta dalam penekanan lebih terhadap makna (Azwar, 2010) . dan metode penelitian kualitatif adalah penelitian yang bertolak belakang dengan penelitian yang bersifat statistic atau bentuk-bentuk dari hitunghitungan dalam hal ini peneliti harus berusaha untuk memaknai atau menafsirkan inti dari suatu fenomena dengan pandangan yang natural, positif dan normal tanpa berpihak, sehingga akan dihasilkan makna yang bisa diterangkan secara nyata yang sesuai dengan teori-teori dan pemahaman-pemahaman yang telah ada (Gunawan, 2016). Data ini menggunakan penelitian kepustakaan untuk mendapatkan data-data sekunder yang dipergunakan untuk bahan penelitian. Langkah penelitian ini adalah dengan pengumpulan bahan data atau studi dokumen dari artikelartikel, jurnal-jurnal, buku-buku, skripsi-skripsi, pendapat para ahli dan hasil penelitianpenelitian yang telah ada berkaitan dengan tema penelitian yaitu E-Government (Hardjaloka, 2014). Penelitian ini mengambil judul Implementasi E-Government Pada Pemerintah Daerah dengan mengambil lokasi di Kabupaten Buton Selatan, unutk mengetahui hasil pencapaian terhadap indikator pengimplementasian E-Government.

\section{HASIL DAN DISKUSI}

\section{Penilaian Penerapan Sesuai Indikator E-Government}

Adapun yang menjadi indikator atau nilai-nilai dasar dalam menentukan sukses dan tidaknya penerapan yang akan dan harus dicapai dalam penyelenggaraan E-Government ada 4 (empat) yaitu efektivitas, efisiensi, transparansi dan akuntabilitas (Azkiya, n.d.). Adapun pencapaian yang sesuai dengan 4 (empat) indikator diatas oleh Kabupaten Buton Selatan dalam pengimplementasian E-Government untuk mewujudkan pengelolaan pemerintahan yang baik sesuai dengan visi dan misinya.

\section{Efektivitas}


Efektivitas adalah kesinambungan atau keseimbangan dari pengeluaran yang dianggarkan dengan hasil yang merupakan tujuan ataupun sasaran yang telah disepakati bersama untuk pencapaian akhir target (Sumenge, 2013). Efektivitas adalah pengukuran untuk mengetahui capaian sejauh mana yang dikeluarkan untuk mendapatkan sasaran yang telah disepakati yang dimana efektif berarti berpengaruh atau berakibat dalam pelaksanaan uuntuk pencapaian sasaran dengan cara yang optimal (Bungkaes, 2013). Efektivitas merupakan ukuran dari hubungan antara pemasukan yang didapatkan dengan apa yang seharusnya dikeluarkan untuk menperoleh pendapatan tersebut secara efektif atau berkeseimbangan (Adelina, 2011) dan dapat peneliti simpulkan bahwa efektivitas adalah cara, tahap, atau sarana penilaian untuk mengukur seberapa berkesimbangan antara hasil yang didapat dengan modal yang dikeluarkan untuk mencapai sasaran pada suatu program-program kerja pemerintahan atau rencana-rencana yang telah di tetapkan. Dan efektivitas adalah salah satu indikator penilaian dalam penentuan kesuksesan atau kegagalan sebuah rencana atau program yang dilaksanakan (Yoduke Ryfal, 2015). Adapun pencapaian terhadap nilai indikator efektivitas penerapan EGovernment di Kabupaten Buton Selatan, adalah penyediaan terhadap sarana dan prasarana oprasional yang mendukung untuk terjalannya pengelolaan pemerintahan yang baik atau Good Government yang telah dijelaskan pada wisi dan misi yang tercantum pada website Dinas Komunikasi dan Informasi Kabupaten Buton Selatan . Berdasarkan data diatas dapat terlihat telah diadakan pemenuhan untuk prasarana sebagai penunjang proses penerapan E-Government di Kabupaten Buton Selatan. pemerintahan yang berkapasitas dan berlandas terhadap kemajuan teknologi informasi dan komunikasi di Kabupaten Buton Selatan sudah berjalan dengan efisien (M.B, 2011). Untuk mencapai tujuan yang telah disepakati dalam visi dan misi Kabupaten Buton Selatan maka di instruksikan untuk peningkatan kualitas bagi sumber daya manusia dalam birokrasi untuk mengasilkan pelayanan yang baik dan efisien dan dengan begitu bisa mencegah atau memberantas adanya praktik Kolusi, Korupsi dan Nepotisme ( KKN ) pada sektor pemerintahan daerah Kabupaten Buton Selatan. Dan selain itu, dengan diberlakukan atau diterapkan Electronic Egovernment sudah membantu memprtmudah pegawai pemerintah dalam mengambil keputusan yang mendapatkan hasil keputusan yang cepat dan akurat karena penerapan E-Government memiliki fungsi untuk pengolahan data dari birokrasi pemerintahan menjadi informasi yang akurat yang dapat di pertanggung jawabkan dalam penggunaannya pada kalangan masyarakat yang membutuhkan (M.B, 2011).

\section{Efisiensi}

Efisiensi adalah keseimbangan atau kesinambungan antara pengeluaran (output) atau hasil kerja dengan penggunaan pembiayaanya yang sehemat-hemat mungkin dengan kata lain serendah-rendahnya (Sumenge, 2013). Efisiensi merupakan pengukuran atau perkiraan pembiayaan yang digunakan untuk pembiayaan pada sektor pembangunan dalam segala sektor pemerintahan yang penggunaan utamanya adalah untuk memenuhi dan menutupi segala yang dibutuhkan oleh masyarakat (sudiro, n.d.). Efisiensi mengandung makna yaitu penerapan Electronic Government adalah bertujuan untuk pengelolaan dan penyelenggaraan pemerintahan dengan signifikan pada kecepatan, ketepatan dan kesederhanaan layanan publik (Kurnia, Rauta, \& Siswanto, 2017). Dapat disimpulkan bahwa efisiensi adalah keseimbangan pendapatan dan pengadaan serta kesinambungan antara pembiayaan yang dikeluarkan sedikit- dikitnya untuk mecapai sasaran yang telah ditetapkan dengan menumbuhkan kualitas pelayanan dan pembangunan yang akan diperuntukan bagi seluruh rakyat di Indonesia(Yoduke Ryfal, 2015).

Keuntungan-keuntungan dari pelaksanaan dan penerapan E-Government adalah meningkatkan kualitas pelayanan untuk masyarakat Kabupaten Buton Selatan, tanpa membebani sektor pemerintahan dengan biaya yang besar bagi sektor pemerintahan karena efisiennya pengelolaan yang didapat sehingga berdampak pada pertumbuhan rasa 
percaya mayarakat. Untuk penerapan sistem teknologi komunikasi dan informasi pada pemerintahan Kabupaten Buton Selatan sudah berjalan dengan baik namun masih berkendala pada kurangnya fasilitas untuk mendukung pelaksanaan secara optimal agar pemerintahan dengan tata kelola yang baik sesuai harapan pemerintah Kabupaten Buton Selatan bisa tercapai (supardal, 2016). dari data diatas dapat terlihat kemudahankemudahan pelayanan yang diterima oleh masyarakat dan pemerintah.

\section{Transparansi.}

Transparansi adalah suatu cara yang bisa mempermudah masyarakat dalam mendapatkan pengetahuan dan informasi yang akurat, cepat, uptodate dan terpercaya dalam hal yang mengenai segala sesuatu yang bersangkutan dengan pemerintahan atau sebagainya melalui media-media yang telah disdiakan oleh pemerintahan tersebut (Amrih Rahayuningtyas \& Setyaningrum, 2018). Transparansi merupakan cara untuk menumbuhkan kepercayaan masyarakat dengan keterbukaan pada segala segi kehidupan pemerintahan yang bisa diakses dan diketahui masyarakat secara luas terkhusus pada bidang yang menyangkut segala hal yang mengenai masalah pemberian jasa pelayanan bagi masyarakat (Kurnia et al., 2017). Adapuan penilaian indikator transparansi pada Kabupaten Buton Selatan adalah sudah baik karena sudah memiliki website sendiri yaitu website dari "DINAS KOMINFO BUTON SELATAN" dimana semua warga Kabupaten Buton Selatan bisa mengakases informasi dan mengetahui bagaimana kinerja dan angaran yang digunakan pada pemerintahan Buton Selatan namun masih banyak yang harus diperbaiki. Pada penelitian (Iiijriiasis, 2016) bahwa transparansi pada Kabupaten Buton Selatan bahwa sistem pelaporan yang sudah diterapkan pada pemerintahan Kabupaten Buton Selatan sudah dengan cara pelaporan yang berbasis pada internet yang dimana sudah dinilai sebagai ketaatan terhadap peraturan yang terlah ditetapkan dan diinstruksikan oleh pemerintah pusat namun masih banyak yang harus diperbaiki karena seyogyanya sistem pelaporan ini masih belum signifikan dalam kriteria pelaporan yang berbasis kinerja dan transparansi pada sistem pemerintahan dan untuk mengurangi segala kekurangan yang telah mengakar melanda sistem pemerintahan di Negara kesatuan republik Indonesia yaitu Korupsi, Kolusi dan nepotisme (KKN).

\section{Akuntabilitas}

Akuntabilitas merupakan keharusan atau pertanggung jawaban dan menerangkan bagi semua intansi dan organisai pemerintahan dalam segala program yang telah dijalankan dan dilaksanakannya dengan segala keputusan serta tindakan yang telah diambil dan disepakati bersama untuk mencapai sasaran dan tujuan yang dihararpkan dan diinginkan dengan kata lain sukses atau gagal semua hasil harus dipertanggung jawabkan (Iii \& Pengertian, 2003). Akuntabilitas merupakan cara utama untuk membentuk tata kelola pemerintahan yang baik dan pemerintahan yang transparansi dalam semua aspek pemerintahannya karena akuntabilitas adalah sarana untuk mewujudkan kepercayaan masyarakat terhadap pemerintahan di Indonesia (fatah rigel nurul, 2017). Definisi lain akuntabilitas dalah kejujuran yang diwajibkan pada pemerintahan sebagai pihak yang memegang kekuasaan terhadap program-program, arahan dan pengambilan keputusan unutk melaporkan hasil kerjanya kepad atasan mauoun masyarakat melalui media-media yang telah disediakan dalam pemerintahan yang berbasis Electronic Government dalam hal ini pertanggung jawaban Sangat berpengaruh besar pada kinerja birokrat pemerintahan (Putra, 2013).

Akuntabilitas sangat erat hubungannya terhadap nilai indikator tranparansi karena jika pemerintahan telah melaksanakan pertangung jawaban dengan didukung sistem media yang menyediakan website-website untuk melampirkan akuntabilitas tersebut makan oemerintahan bisa dikatakatan transparan dan terbuka untuk informasi tata kelolanya. Terlihat nilai akuntabilitas di Kabupaten Buton Selatan dalam penelitian dari (fatah rigel nurul, 2017) tentang akuntabilitas terhadap oengelolaan Anggaran Dana Desa ( ADD ) di Kabupaten Buton Selatan sudah baik namun pada dasarnya karena penerapan E- 
Government masih terbilang baru dan mengalami perubahan secara cepat sehingga birokrat pemerintahan Buton Selatan masih memerlukan dampingan terkhusu pada penyesuaian terhadap perubahan yang terjadi disetiap tahunnya.

\section{KESIMPULAN}

E-Government adalah tata kelola pemerintah dengan menggunankan teknologi informasi dan khususnya internet sebagai salah satu alat pemerintah untuk meningkatkan pelayanan pemerintah kepada warga Negara, lembaga swasta dan lembaga pemerintahan lain yang saling berinteraksi. Penerapan E-Government ini berfaktor Karena pemerintahan ingiin menyesuaikan diri terhadap zaman dan era modern dan lagi terdapat banyaknya masalah yang mengakar dan mendarah daging pada badan pemerintahan di indonesa yaitu Banyaknya kasus korupsi, Kolusi dan nepotisme yang melanda pemerintahan di Indonesia yang mana muncul karena sifat monopoli pemerintah yang ingin memegang kekuasaan seluruh pemerintahan dengan mengendalikan segala potensi yang ada di Negara ini. Adanya banyak penyalahan gunaan wewenang (Diskresi) oleh pejabat-pejabat pemerintahan dan pejabat publik dengan begitu terbuka lebarnya korupsi dan pungutan liat dalam penurusan perizinan yang dimana terjadi karena prosedur yang panjang dan sangat kompleks. Minimnya kepercayaan masyarakat kepada pemerintahan dan pertanggung jawaban pejabat pemerintahan terlihat pada cara pengambilan keputusan dan tindakan-tindakan yang dimana dipercayai dengan menerapkan teknologi komunikasi dan informasi kedalam bidang pemerintahan untuk meningkatkan keterbukaan pemerintahan dan partisipasi masyarakat.

Perapan atau pengimpelemtasian E-Government di Kabupaten Buton Selatan sudah berjalan dengan baik, yaitu telah mentaati regulasi atau peraturan yang diinstruksikan dari pemerintah pusat untuk memanfaatkan kemajuan teknologi komunikasi da informasi kedalam peroses tata kelola pemerintahan daerah di seluruh Indonesia. Dalam penerapan ini Kabupaten Buton Selatan telah mencapai nilai Baik pada disetiap indikator yang menjadi dasar penilaian terhadap rencana, proses, jalan dan hasil yang telah dicapai sesuai dengan sasaran yang telah ditetapkan yaitu efektivitas, efisiensi, transparansi dan akuntabilitas. Namun, karena Indonesia masih baru mengeluarkan instruksi penerpaan electronic dalam sistem pemerintahan, maka masih terdapat banyak hal yang harus di perbaiki dalam penerapan ini, terlebih lagi untuk sarana dan prasarana yang akan mendukung jalannya penerapan tersebut dan lagi masih banyak birokrat yang masih membutuhkan pendampingan dalam pengelolaan pemerntahan yang berbasis electronic ini sehingga pemerintah Indonesia bisa menyesuaikan diri terhadap kemanjuan zaman di era globalisasi.

\section{REFERENSI}

Adelina, R. (2011). Analisis effektifitas dan kontribusi penerimaan pajak bumi dan bangunan (pbb) terhadap pendapatan daerah kabupaten gresik. E-Jurnal Akuntansi Universitas Negeri Surabaya, 1(87), 1-20.

Amrih Rahayuningtyas, D. P., \& Setyaningrum, D. (2018). Pengaruh Tata Kelola dan EGovernment terhadap Korupsi. EKUITAS (Jurnal Ekonomi Dan Keuangan), 1(4), 431. https://doi.org/10.24034/j25485024.y2017.v1.i4.2597

Arsik, S. F., \& Lawelai, H. (2020). PENERAPAN AKUNTABILITAS, EFEKTIVITAS, DAN TRANSPARANSI DALAM MEWUJUDKAN GOOD GOVERNANCE: STUDI PEMERINTAH DESA BANABUNGI. Jurnal Studi Ilmu Pemerintahan, 1(1), 1-7.

Azkiya, H. (n.d.). penerapan e-government dalam peningkatan pelayanan publik, 0714111330.

B. Ngoqo and K. Njenga, "The State of e-Government Security in South Africa: Analyzing the

National Information Security Policy," in e-Infrastructure and e- Services for Developing Countries, South Africa, 2018

Bungkaes, H. R. (2013). Journal “ACTA DIURNA” Edisi April 2013, (April), 1-23.

Data, B., \& Dan, P. (2006). Basis data peraturan dan perundang-undangan. Program, 1-14.

49 Karman; Rudi Deswanto; Sri Adhi Ningsih, JSIP Volume 02 No. 02 Agustus 2021 
Edwi, A. S. (2008). Evaluasi Implementasi E-Government Pada Situs Web Pemerintah Daerah Di Indonesia: Prespektif Content dan Manajemen. Seminar Nasional Informatika 2008 (SemnasIF 2008), 2008(November 2007), 88-98. Fatah rigel nurul. (2017). akuntabilitas pengelolaan ADD Bantul, 2(2). Gubernur, \& Yogyakarta daerah Istimewa. (2013). No Title.

M. H. Tjiptabudi and R. Bernandino, "Information System Security of Indonesia Terrestrial Border Control," CommIT (Communication \& Information Technology), vol.13(2), pp. 45-56, 2019

M. Nicho, "A process model for implementing information systems security governance," Information and Computer Security, vol. 26, no. 1, pp. 10-38, 2018.

J. Wu and Z. Zheng, "A PaaS Based E-government Security Framework and Its Application," in International Conference on Software Engineering and Service Science (ICSESS), 2016

Hardjaloka, L. (2014). Studi Penerapan E-Government Di Indonesia Dan Negara Lainnya Sebagai Solusi Pemberantasan Korupsi Di Sektor Publik. Jurnal Rechts Vinding: Media Pembinaan Hukum Nasional, 3(3), 435-452. Retrieved from http://rechtsvinding.bphn.go.id/ejournal/index.php/jrv/article/view/35

Holle, E. S. (2011). PELAYANAN PUBLIK MELALUI ELECTRONIC GOVERNMENT: UPAYA MEMINIMALISIR PRAKTEK MALADMINISTRASI DALAM MENINGKATAN PUBLIC SERVICE Oleh: Erick S. Holle. Jurnal SaSi, 17(3), 21-30. https://doi.org/10.1371/journal.pone.009299 